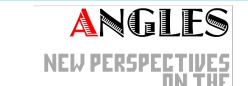

ANELOPHONE WORLD

\section{Angles}

New Perspectives on the Anglophone World

5 | 2017

The Cultures and Politics of Leisure

\title{
Early Tourism in New Mexico: A Primitivist Pastime or a Tool of Integration?
}

\section{Susanne Berthier-Foglar}

\section{(2) OpenEdition}

1 Journals

Electronic version

URL: https://journals.openedition.org/angles/1268

DOI: $10.4000 /$ angles. 1268

ISSN: 2274-2042

\section{Publisher}

Société des Anglicistes de l'Enseignement Supérieur

\section{Electronic reference}

Susanne Berthier-Foglar, "Early Tourism in New Mexico: A Primitivist Pastime or a Tool of Integration?", Angles [Online], 5 | 2017, Online since 01 November 2017, connection on 07 June 2022. URL: http://journals.openedition.org/angles/1268 ; DOI: https://doi.org/10.4000/angles. 1268

This text was automatically generated on 7 June 2022

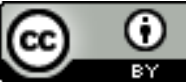

Angles est mise à disposition selon les termes de la Licence Creative Commons Attribution 4.0 International. 


\title{
Early Tourism in New Mexico: A Primitivist Pastime or a Tool of Integration?
}

\author{
Susanne Berthier-Foglar
}

\section{Introduction}

1 In the late $19^{\text {th }}$ century and the first decades of the $20^{\text {th }}$ century the culture of leisure came to New Mexico as a by-product of transcontinental railroad travel. Leisure in Thorstein Veblen's (1899) definition as "abstention from labour" and the pursuit of a non-economic activity affirming "evidence of wealth" and "social standing" (21) wasin New Mexico at the time-the attribute of white Americans of urban origin traveling to a remote region of the country. In contrast, the visited peoples were mostly tribalized Native Americans with the Hispanic population coming in second as a tourist attraction. There had been "Anglo" visitors to New Mexico in the early Territorial period (post-1846); however, since they were military men, traders or administrators of the Territory, they did not undertake the trip for mere enjoyment despite the fact that they laid-through their writings about people and places-the foundation for the vision of later travelers. What was new in the 1880 s was the acceptance of nonutilitarian traveling. The early tourists came to New Mexico to simply enjoy the trip despite the accepted notion that one would profit, in an educational way, from the journey, much as the $18^{\text {th }}$ century British "grand tourists" broadened their worldview. In New Mexico, the picturesque views of natural wonders were not the main attraction, as they were at the Grand Canyon and the Yellowstone; it is in a large part the indigenous and their way of life who became the local specialty as exotic Others. The authentic setting and the historic villages (i.e. Pueblos) contributed to the feeling that the tourist was experiencing the persistence of history and of the Others' culture.

2 This paper is about the dynamics opposing the tourists' aspiration for a primitivist experience in exotic authenticity (Thomas 19) seen as an antidote to the fast-paced city 
life, surrounded with standardized products, and the indigenous wish to be left alone and, more specifically, to avoid interference by federal authorities threatening their way of life. I will attempt to trace the evolution of the discourse created by the service sector marketing tourism in Indian ${ }^{2}$ country and reinforced by the indigenous people(s) themselves who have built upon a fairly standard marketing rhetoric to transform it into their own cultural manifesto. The paper starts with a case study of the marketing of leisure in New Mexico, discusses the interference of primitivist cultural tourism with federal policies of assimilation and concludes with an analysis of the persistence of the discourse created by the leisure industry about indigenous landscapes and peoples and perpetuated by the Indigenous themselves.

\section{The railroad services to travelers}

\section{The Southwest becomes accessible}

While the transcontinental railroad had a geopolitical purpose, its role in transporting tourists emerged shortly after its completion. The Southern route of "the Santa Fe", as it was called in New Mexico, reached Albuquerque, New Mexico, in 1880 and continued to the West (Bryant 62). It was immediately used by the expeditions of the newly created Bureau of Ethnology on their way to study the Zuni in Western New Mexico (DeGolyer. "Zuni and Cushing." 14). Other expeditions and individual researchers followed, each producing a bounty of documents, including a wealth of articles and books targeting the general public and putting New Mexico on the map as the place in the United States where one could see the original inhabitants in their ancestral dwelling places.

4 Early non-academic publications, the forerunners of travel literature, appeared in the 1880s. Susan Wallace, the wife of New Mexico's Governor Lew Wallace, wrote about her visits to the remote area (Land of the Pueblos. 1888), and Charles Fletcher Lummis (1892), a journalist who crossed the continent on foot wrote about his travel experience among the Pueblos. He also gave 'curiosity' about his country as the main reason for his trip: "I am an American and felt ashamed to know so little of my own country as I did, and as most Americans do," but he was also eager to admit that the trip "was purely 'for fun', in a good sense" (Lummis 1892: 2). Academics also wrote for the general public creating a strong incentive for the tourists to include these small indigenous groups in their visits, villages (Pueblos) of several hundred inhabitants at most. Tailoring their publications to their readership, the travel authors often included the term "adventure" as a means to insure better circulation. Thus, ethnographer Franck Hamilton Cushing wrote an account of his "adventures" among the Zuni, originally published in The Century Illustrated Monthly Magazine (Cushing 1882-83).

5 A major purpose of early tourist endeavors in New Mexico was thus to see the original inhabitants in their ancestral villages, going about what was imagined to be their daily lives since time immemorial. While the term cultural tourism would be used only in the last decades of the $20^{\text {th }}$ century (McKercher and DuCros 6) its New Mexican roots reach back to the scientific study of the Southwestern tribes. 


\section{Catering for the traveler along the railroad: The railroad stops as tourist destinations}

6 Traveling per se gradually became accepted as leisure with an educational purpose (Veblen 24). Since the travelers came from the middle and upper classes of society (McCannel 13), they also expected to travel in comfort. Early transcontinental railroad travel did not cater to the bodily needs of the passengers who had to provide for their own meals or purchase substandard fare at railroad stops. To make traveling more comfortable, businessman Fred Harvey (1835-1901) in agreement with the Santa Fe railway company opened restaurants-and later hotels-catering in style to the railroad passengers. From the first restaurants, opened in the late 1870s, to the 1940s signaling the demise of rail travel, the Fred Harvey Company had opened 84 establishments. In New Mexico, some of them became what we call today "destination hotels," i.e. places one would travel to because of what they offered and where the traveler was tempted to spend more than one night. The most famous in New Mexico were the Montezuma (opened 1882) and the Castaneda (1898), both in Las Vegas (NM) as well as the Alvarado (1902) in Albuquerque (Bryant 111-2). All of them had a link to local culture through their architecture or their interior decoration.

\section{Proto-pueblo architecture: Mary Colter's designs}

7 As his chain moved to the west, Fred Harvey wanted to imbue his hotels and restaurants with a regional flair and he hired architects who experimented with the local vernacular, taken in a very broad geographical sense as it came to include elements copied from the Franciscan adobe churches of Northern New Mexico, and the Californian Missions, alongside with real elements from historic pueblos. In this experimental context, Harvey hired a young industrial designer, Mary Colter, who was at first in charge of interior design such as lunchrooms and lobbies, and soon moved on to larger projects. Her style vocabulary based on "stair-step buttresses, projecting roofbeams, stone roof-drains, and chimneys made of old pottery" (Wilson 113-4) became the trademark of the proto-pueblo style that evolved into the "Santa Fe style" and led to a consensus-in the first decades of the $20^{\text {th }}$ century-to impose a strict building code in the urban area of New Mexico's capital. Today's view of the city's famous plaza surrounded by two-story buildings in either one of the approved styles (proto-pueblo and its "Territorial" variant with Greek revival details) with wide portales (i.e. pedestrian porches) along the streets feels historic while it was designed to pander to the tastes of the visitors.

\section{The Indians and the manufacture of tourist trinkets}

8 Herman Schweizer, the manager of a railroad stop on the Santa Fe line in Navajo country who operated a restaurant business, added a line of Navajo rugs and jewelry and sold them to the travelers. His success prompted the Harvey Company to add tourist shops at other locations (Bryant 119-120). For Martha Weigle, the display of Indian crafts and selling of Indian ware at the railroad stops occurred at a time when the traveler was not yet ready to leave the tracks to explore the country ("From Desert to Disney World." 21) but it would lead the way for a more intimate tourist experience. However, Indians soon became active participants in the tourist economy as the turn of 
the century and the first decades of the $20^{\text {th }}$ century saw the emergence of a lively market for handmade goods. The Arts and Crafts movement had led the way toward the fashion for hand-wrought items whose "visible imperfections" exalted "the defective" (Veblen 74). The tourists in search of the primitive were on the same track.

The fact that the manufacturers of the goods were Indians, a group still said to be primitive-not taken in a negative sense-added a strong marketing argument. Purchasing an Indian-made object was a way to counter the overwhelming presence of industrial goods that had become the norm in the first decades of the $20^{\text {th }}$ century. Northern New Mexico thus became a haven for an escapist movement-composed of artists and intellectuals-acknowledging the cultural importance of the indigenous inhabitants of the continent (Jacobs 59-60). While it may be claimed that the production, by the Indigenous, of tourist trinkets is linked to the commodification of their culture, the reality is that tribal communities also profited from selling their wares at the railway stops, in "curio shops," and in museum stores as it provided families with much needed income while enabling them to stay in their home villages (Lange 1953). The success of the tourist trade led Fred Harvey to hire resident artists who lived on the premises of the Harvey establishments, often in constructed "Indian Villages," and who would demonstrate their skills for the tourists in an authenticlooking setting reminiscent of World Fair exhibitions. While the "tourist gaze" (Urry 51) in such settings was particularly intrusive, it also fostered cultural pride in the participating craftspeople and allowed the emergence of artistic careers. Two female potters, Nampeyo (Hopi) and Maria Martinez (San Ildefonso Pueblo) both launched successful careers and supplemented their family income with the sale of their artistic production (Howard and Pardue 109). Even today, pots by the prolific Maria Martinez grace the shop-window displays of upscale galleries.

\section{Cultural tourism versus federal assimilation policies}

\section{Indian Detours: Organizing the "tourist gaze"}

Fueled by early travel narratives, and mainstream ethnographic publications, the "tourist gaze" has also been modeled by Fred Harvey's marketing discourse. Through his Indian Detours company he started to offer scenic Harveycar limousine tours into Indian country, guided by fashionably clad couriers, young women originally dressed in Navajo blouses and skirts and adorned with silver squash-blossom jewelry and concha belts (Indian Detours. Brochure. 1930). The Indian Detours brochures were keen to inform the traveler that the women hired by the Courier Corps were often college graduates, knowledgeable "in one or more foreign languages aside from Spanish" and had undergone a four-month training cycle of book work, field trips, and lectures by the leading authors in Southwestern ethnography, archaeology and history. Moreover, the training was organized in cooperation with the University of New Mexico (Indian Detours. Brochure. 1930). The main tour desk of the company was based at Santa Fe's La Fonda Hotel, and the detourists, as they came to be called, had access to a lecture lounge and a reading room stocked with Southwestern classics. The tours themselves were meticulously organized to various locations including Pueblo villages and places of archaeological interest. Contact with the inhabitants involved purchasing crafts and attending tribal ceremonials. Harvey's marketing discourse aimed at presenting the 
Detours as an exclusive off-the-beaten-path experience, away from "the steel ribbons of the railroads"-belittled as "iron-spiked lines of least resistance"-to places were ancient cultures could be experienced first-hand (Indian Detours. Brochure. 1930).

Overnight tours often came back to the La Fonda, as accommodation was scarce in the backcountry. The travelers who visited the prehistoric Puyé Cliff dwellings and the archaeological excavations at Frijoles Canyon (in Bandelier National Monument), stopped in pueblos on the way, most notably in San Ildefonso, to visit the private homes, meet the potters and purchase their wares. Other trips were scheduled to local Pueblos in time for ceremonial dances. Archival photos of the 1930s show that the cars and buses of Indian Detours invaded the Pueblos, their massive bulk parked right on the plazas where the ceremonies were taking place. The terraced roofs of the houses surrounding the event were largely occupied by tourists who crowded out the locals, hogging the best seats. The "tourist gaze" (Urry) had become a codified practice of consuming experiences at the expense of the local inhabitants (McKercher and du Cros 9; McCannell 21). After the tours, the shopping for crafts, the attendance of ceremonials, the tourists retreated to have tea, dinner, and a dance to a Mexican orchestra, or a "Southwestern talk" in the Indian Lecture Lounge (Indian Detours. "Roundabout Old Santa Fe" 1930).

The situation appears crassly colonial as it seems that the experience of the Others' culture was limited to sampling a primitivist experience before retreating to the comfort of Western "Anglo-Saxon" hospitality. However, the long-term effects of tourism on tribal communities have to be viewed in a more favorable light. The early decades of the $20^{\text {th }}$ century have not witnessed the destruction of tribal culture. Pueblo and Navajo artists have produced goods for the market. However, from craftspeople they have often become artists. In the formative years of the market they were often counseled by traders so as to adapt their creations to consumer tastes and market trends. Indigenous objects were adapted to the needs of the buyers, large ollas (jars) would become table lamps, carpets were produced in the colors in fashion in mainstream decorating, small and portable objects were produced to fit into travelers' suitcases (Howard and Pardue 126). While in the beginning these trends were largely due to the presence of mainstream art dealers, they have been integrated by the indigenous artists who have developed a feeling for the market. The tribal Indian has been fetishized by the gaze of the dominant group in search of exotic authenticity (Thomas 19, 98), however, in the long run, i.e. two to three generations later, the Indigenous Other remains profoundly Indian.

\section{Pueblo response: Secrecy as a survival technique}

13 Tourism theorists question the authenticity of staged performances and cultures kept alive for visitors (McKercher and DuCros). However, the situation of the Pueblo derives from over four centuries of colonization and assimilation policies. With the Spanish colonization starting in 1598, they were Christianized, at least superficially as it appeared they had added the Christian God, Jesus, and the Virgin Mary to their original pantheon, calling upon their own sacred entities whenever they felt that the new religion was not effective. Since the Padres kept a watchful eye on their flock, ancient ceremonies often had to be conducted stealthily and when disobedience became apparent, repression was swift and violent. In 1680, a major rebellion took place, 
ousting the Spanish colonials for at least 12 years, and a smaller aftershock occurred in 1696 (Berthier-Foglar). The long habit of scrutiny by outsiders, as well as their profound wish to be left alone, has led to a culture of secrecy that has constantly been reinforced throughout the $20^{\text {th }}$ century (Brandt 124). Regulations concerning the presence of outsiders have become stricter over time. While in the 1930s the Detourists parked their cars on the plazas, it has been observed that in the 1980s parking was limited to fields outside the pueblos, and in the 1990s fee-parking was set up in enclosed areas further away from the plazas (personal observations 1982 to 2016). The Pueblo have transformed an intrusive situation into a business-like endeavor whereby a service rendered requires the payment of a fee.

It is not the point here to discuss the advent of capitalism among the Indigenous as a replacement of communal agriculture supplemented by hunting and gathering. Of importance here is the fact that the Pueblo are free to manage and control access to certain sites on their land, and to impose rules in accordance with the US Code of laws giving the tribes jurisdiction over certain areas of their administration. The mere fact that the colonized indigenous are able to impose their rules has an empowering effect (Urry 127).

\section{The federal Indian policy of assimilation versus the primitivists}

Pueblo secrecy was also in part dictated by the assimilationist policies of the federal government. During the Indian Detours period of the first decades of the $20^{\text {th }}$ century, the federal government was active in promoting the assimilation of Indians into the mainstream. Residential schools taught manual skills to Indian children, girls learned how to manage an American household, a home furnished with a table, chairs, and the basic implements of a kitchen, as opposed to the open hearth and floor mat seating of a Pueblo household. Since it was believed that assimilation was most effective when targeting women, the Indian office had set up a service of visiting "field matrons," female agents to the tribe who were to advise women on questions concerning cleanliness and morals. These matrons reported to the local Superintendent of Indian affairs and informed him of the progress of assimilation. They were active at the same time as the tourists came specifically to witness authentic tribal ceremonies while tending to shun situations where obvious assimilation had occurred (Jacobs 51-5).

In the 1890s, the last "Indian war" was over, and the push to teach Indian children in residential schools was at its highest. However the American public, mostly urban and Eastern, showed an avid interest in the old and disappearing frontier days and in real Indian warriors. The World Exhibitions exhibited people for an educational purpose, alongside the inventions and technical achievements of the day, and showman Buffalo Bill made a career of staging the Old West, including Indian attacks on a stagecoach. For this purpose, real Indians were hired, preferably those who had participated in the Indian wars and who looked the part (Kasson 97-87). Critics from the federal government argued that the theatrical representation of Indian warriors in action glorified their "savage past" and they attempted to outlaw their participation in the show. The Indian Office reluctantly gave permission to Buffalo Bill to hire one hundred Indians for the 1893 Columbian Exposition in Chicago and the Wild West Show was a success (Prucha 712-715; Gallop 40). The detourists as well as other primitivists from the New Mexican art colony went a step further and visited tribal Indians in their 
Pueblos. However, Indian Affairs officials were not pleased with the budding tourist industry in the Southwest.

For the next decades, until 1933 and Franklin Roosevelt's Indian New Deal, subsequent Commissioners of Indian Affairs have unsuccessfully tried to ban Indian performances in shows and to regulate practices deemed offensive. However time did not alter the white public's wish to gaze at "the savage" and tourism into Indian country changed the problem as at this time it was the viewers who traveled to the performers. In 1921 Commissioner Charles Burke explained in a circular to the Superintendents of Indian Affairs the necessity to legislate against the Lakota Sundance-considered offensive because of self-inflicted wounds-the practice of the give-away-considered contrary to market-economy-and all the dances involving what was seen as "immoral relations between the sexes". His philanthropic goal was to prepare Indians for survival "in the midst of all races" and he considered dances inconsistent with "civilization" as they "retain[ed] elements of savagery of demoralizing practices" (Burke. Circular 1655. 1921). To achieve his ends, he declared that the ceremonial dances were akin to a leisure activity for the participants, to be performed for "pleasure and relaxation" and that they thus could be limited in time and duration so as not to impinge on the regular working hours. Burke failed, or refused to consider their profound religious value and accepted that they were at most "healthful exercise." For those who disregarded his ban, he envisioned "punitive measures" to eradicate tribal ceremonialism (Burke. Circular 1655. 1921).

18 Two years after his 1921 circular, Burke issued a supplement to the Superintendents, adding that the conference of missionaries, held in 1922, reinforced his opinion on the strategy to minimize the existence and impact of dances (Burke. Supplement to Circular 1655. 1923). Burke's insistence implies that Circular 1655 had not achieved its intended goal. In his 1923 Supplement to Circular 1655, Commissioner Burke presented his plan of action to eradicate all forms of Indian ceremonials. He set out to severely curtail the number of hours taken up by the ceremonials: "limited to one in each month in the daylight hours of one day in the midweek, and at one center in each district; the months of March and April, June, July and August be excepted." Since ritual dances are determined by cosmic occurrences, reorganizing their timing, and shortening the rituals to the daylight hours of one day, led to a loss of religious meaning, and effectively transformed the dances into "entertainment." Moreover, by not allowing night ceremonials, the federal power attempted to keep an eye on the events, although it would have been imaginably difficult to implement such a rule. As if the above was not efficient enough, Burke added: "That none take part in the dances or be present who are under 50 years of age," thus attempting to prevent the transmission of ceremonial knowledge. As for the tourist industry, Burke added "That a determined effort be made by the Government employees in cooperation with the missionaries to persuade the management of fairs and "round-ups" in the town adjoining the reservations not to commercialize the Indian soliciting his attendance in large numbers for show purposes" (Burke. Supplement to Circular 1655. 1923).

In the Southwest, as elsewhere, Burke's Circular went unheeded and the tourist business in Indian Country flourished. In 1924, the Commissioner issued a Second Supplement to Circular 1665, because "so far not many Superintendents have responded". (Burke. Second Supplement to Circular 1655. 1924). Meanwhile a vibrant intellectual community was established in Taos, under the leadership of Mabel Dodge, 
patroness of the arts, who married Tony Luhan, a Taos Pueblo Indian, and who invited influential individuals from around the world, including D.H. Lawrence and Carl Gustav Jung, whom she believed to be able to inform the world that the Pueblo have the answer to the ailments of modern society (Luhan 1937). Adding to the publicity created about the Pueblo, Charles Lummis who had gained fame through his walk across the continent published Mesa, Cañon and Pueblo extoling the virtues of a people who are "the original, the First Americans" (Lummis 1925: 203). It seemed that two worldviews coexisted without intersecting, the assimilationist program of the federal government and the tourists' and intellectuals' vision of the Indian as relic of a potent primitive world, a classic case of fractured and contradictory colonial projects (Thomas 97).

\section{The persistence of an imposed discourse}

\section{The positive side of tourist income (Meriam Report)}

How did the Pueblo survive the discourse imposed upon them by the tourist industry and by the primitivist intellectuals seeking answers from the Pueblo? It is interesting to see that what the administration has called the "Indian Problem" from the late $19^{\text {th }}$ century to the 1930s has been analyzed from various viewpoints. In the 1890s, the debate was dominated by the "Friends of the Indians," philanthropists meeting yearly to discuss in a paternalistic setting how mainstream America could help the Indians to assimilate into white society (Prucha 611-623). A consensus emerged that land held in severalty was the roots cause for tribalism and the lack of assimilation and that an allotment policy redistributing reservation land (i.e. land held in trust by the government for the tribes) to Indian individuals, with the view that they would become individualistic farmers, would automatically favor their assimilation (Prucha 659-681).

Meanwhile-up to 1917-demography confirmed that the Indians were dying out and the intended results of the 1887 Allotment Act did not materialize. Tribal and detribalized Indians lived in dismal conditions, marred by poverty and disease, they were plagued by anomia leading to self-destruction, and the administration requested yet another assessment of the "Indian Problem." The 872-page report entitled The Problem of Indian Administration, or Meriam Report after his main author, was published in 1928. The team of the Institute for Government Research hired for the extensive surveys in 1926-27 comprised policy specialists, field-workers and one Winnebago Indian, Henry Roe Cloud, who had a degree in anthropology. The report came to the general conclusion that the economic situation of the tribes was not viable:

The economic basis of the primitive culture of the Indians has been largely destroyed by the encroachment of white civilization. The Indians can no longer make a living as they did in the past by hunting, fishing, gathering wild products, and the extremely limited practice of primitive agriculture. The social system that evolved from their past economic life is ill-suited to the conditions that now confront them, notably in the matter of the division of labor between the men and the women. They are by no means yet adjusted to the new economic and social conditions that confront them. (Meriam Report. Chapter 1)

However, the surveyors noted that the Pueblo stood out among all the other Indians as they had a functional economy based on traditional crafts, mainly pottery, which they sold "at good prices, directly to tourists" (Meriam Report. 532.) Moreover, the Pueblo women were not the typical 'drudges' who had to submit to 'brute and savage' 
husbands, refusing their advancement to the status of independent woman (Jacobs. Engendered Encounters. 52). Since the surveyors were impressed by the positive economic development, they recommended that other tribes follow the same path (Meriam Report. 125). In the 1920s, the assimilationist policies of the Indian administration started to show cracks, and they were fueled in part by tourism as a purveyor of eager audiences for Indianness and as an outlet for Indian crafts.

The often-voiced criticism of tourism in an underdeveloped region as an imperialistic endeavor (Smith 4) is therefore misplaced in the case of the Pueblo who have been able to set their own agenda. For Nicholas Thomas $(51,97)$, the contradictory "colonial projects" can be profitable to colonized cultures as the colonial government (in the broad sense, Thomas includes civil and religious authorities under the heading) does not have a unanimous position when dealing with the natives. In the case of the Pueblo, coexisting visions of assimilation and cultural makeover coincided with a primitivist admiration for tribal culture. Their long habit of secrecy enabled the Pueblo to cater in a minimalistic way to the tourist industry while preserving their identity. However, there is no question that the tribal culture has been transformed over the decades, especially as the economic basis shifted from traditional occupations to wage work. Nevertheless, the Pueblo have accepted as their own the discourse of the tourist industry regarding their identity, and culture. More specifically they even have accepted the aesthetics of Anglo representation of Pueblo identity. As proof one needs only to look at George Dorsey's Indians of the Southwest, published in 1903 by the Atchison Topeka \& Santa Fe Railway System to promote tourism in Pueblo country The author is curator of anthropology and he has called upon illustrator A. S. Covey to create chapter headings and drop caps reminiscent of medieval manuscripts and representing traditional motives transformed into westernized designs (Figure 1). 


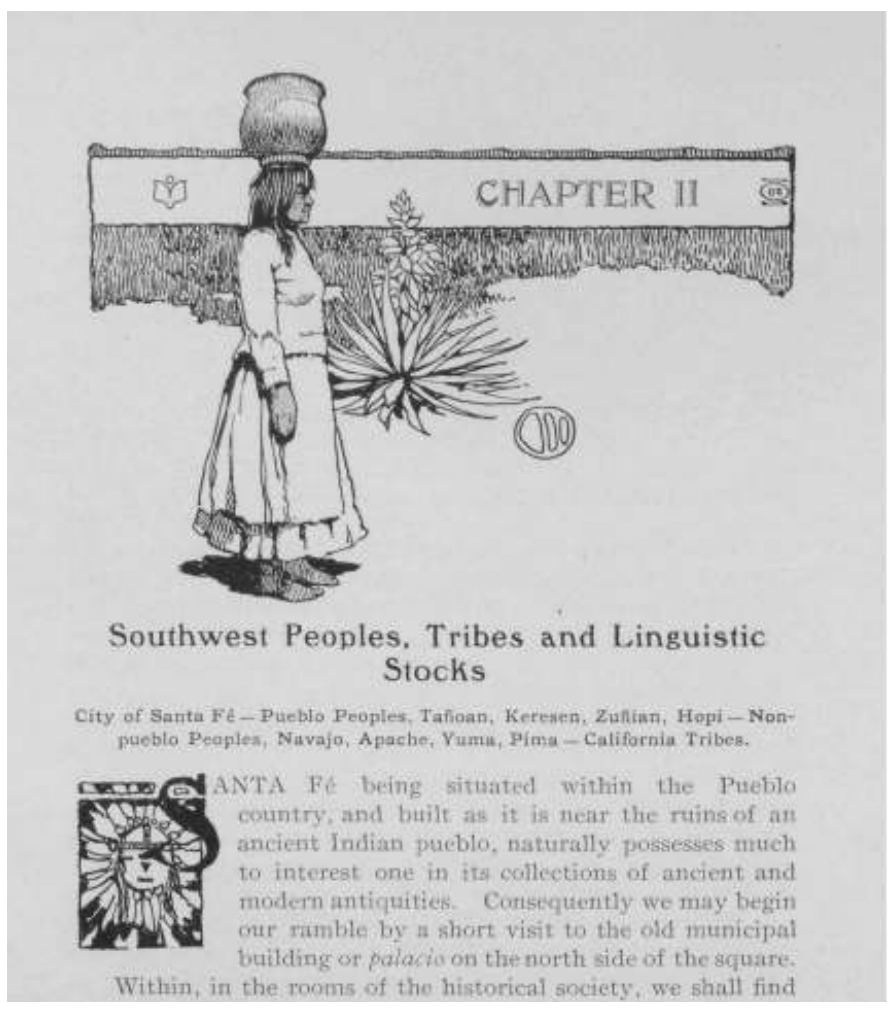

Designs by A.S. Covey. 1903. 21

\section{The Santa Fe Indian Market}

In 1922, white philanthropists, called "Indian lovers" by their detractors, organized the first Indian Market in Santa Fe as a showcase for local arts and crafts. They set up juries per type of artwork and awarded prizes for the best in each category. In the beginning both the organizers and the juries were "Anglos" and they pushed in a paternalistic and protective fashion for legislation that would protect the Indian craftsperson-the first Indian Arts and Crafts Act was passed in 1935 (Mullin 132.) While the legislation was imposed from the outside it also responded to the needs of Indian crafts people and ultimately favored their production over the wares of non-Indian producers. Over time, the Indian crafts people and artists gained visibility and independence from the promoters and buyers of Indian Detours. The rules gradually changed and power is now in the hands of the formerly colonized. Nevertheless, the aesthetics of the high-quality arts and crafts, the jewelry, the weavings, and the paintings still bear the mark of the early $20^{\text {th }}$ century tourist illustrations (Dorsey. The Indians of the Southwest; the Indian Detours brochures). One may question whether it is due to the tastes of the public, expecting a certain type of motives, or whether it is the native artists themselves who have internalized the design. Both factors are probably involved. However, whether the former takes precedence over the latter, or not, is relatively unimportant when considering the absence of blatant commodification of indigenous culture and the fact that the artists and craftspeople are able to sell their production at a fair price. 


\section{Conclusion: Is tourism exploiting or integrating the Indigenous?} whether tourism is exploiting or integrating the Indigenous is relevant. However, the Indigenous are not passive victims of the tourist gaze (Nash) and they deliver-up to a certain point-what is expected of them. They pursue a strict policy of secrecy to reserve certain rituals for insiders. From the point of view of marketing, the scarcity of ceremonials creates a demand that draws visitors. Their authenticity-they have a function for insiders-draws tourists to view them and to buy the authentic, the indigenous, the handmade item produced by the group.

This paper set out to explore the dynamics opposing the tourists' aspiration for a primitivist experience and the indigenous wish to be left alone. The two groups still coexist in symbiosis. The tourists are still in search of a primitivist experience, accepting the rules the Pueblo have set up to regulate visits by outsiders, and even accepting a tightening of the rules, with more ceremonies and places that are off limit. The Pueblo still fight to keep their identity alive, setting up a niche economy in profitable casinos that enable them to finance what could be called their lifestyle, such as an anachronistic looking buffalo herd owned by the Pueblo of Sandia on the outskirts of Albuquerque, next to a typically American suburban (non-Indian) housing project. the early $20^{\text {th }}$ century tourist industry, not a single pueblo has set up a business of "plastic medicine men, "i.e. fake shamans, that no pueblo has a tourist facility inside the old village. At most a few tourist stands selling crafts are open at hours determined by the tribe (and not by the market) in places such as Taos Pueblo. When tourist facilities have been built by the tribes, including casinos, they are located as far as possible from the tribal living quarter on the outskirts of the tribal territory, along an already blighted thoroughfare.

According to McKercher and du Cros, "academic literature is replete with stories portraying tourism as a destroyer of communities" (McKercher and du Cros 26-28). The present example of the interaction between a leisure seeking public, eager to pay for a primitivist experience, and small groups of indigenous peoples who could easily have disappeared within a generation, is a demonstration that the dynamics can favor the Indigenous.

In the case of Northern New Mexico, tourism has participated in the survival of Indianness and also in the economic integration of the tribes. Even in the presence of a tourist economy, with strong economic ramifications into tribal economies, the communal life of insiders takes precedence over the tourist activity. Taos Pueblo, which is on the UNESCO World Heritage list, closes down for visitors for several hours during funerals, obviously unannounced events. Other pueblos operate a "closed pueblo policy" and open only on certain days. Violators who disregard the no trespassing sign are said to be prosecuted according to the posted signs. It seems tourism has become a tool of integration while elements of what was formerly called "primitive" survive (non-Christian ceremonials for instance) moreover tourism has not destroyed those who were formerly the seemingly passive object of the "tourist gaze."

Angles, 5 | 2017 


\section{BIBLIOGRAPHY}

\section{Primary sources}

Burke, Charles H. Commissioner of Indian Affairs, Circular 1655 to the Superintendents, April 26, 1921. National Archives, Washington D.C.

Burke, Charles H. Supplement to Circular 1655 to the Superintendents, February 14, 1923. National Archives, Washington D.C.

Burke, Charles H. Second Supplement to Circular 1655 to the Superintendents, March 4, 1924. National Archives, Washington D.C.

Davis, William H. El Gringo or New Mexico and Her People. New York: Harper and Brothers, 1857.

DeGolyer, E. "Zuni and Cushing." My Adventures in Zuni. Santa Fe, New Mexico: The Peripatetic Press, 1941. 11-24.

Dorsey, George Amos. Indians of the Southwest, with illustrations by A.S. Covey. Atchison Topeka \& Santa Fe Railway System, 1903.

Drumm, Stella M. Down the Santa Fe Trail and into Mexico. The Diary of Susan Shelby Magoffin, 1846-1847. Lincoln: U. of Nebraska P., 1926.

Gregg, Josiah. Commerce of the Prairies, 1844. Kansas Collection Books. https://www.kancoll.org/ books/gregg/

Indian Detours Brochures, 1930 to 1946, notably: "Indian Detours - Most Distinctive Motor Cruise Service in the World." 1930. "Off the beaten path in the great Southwest." 1936. "Indian Detours Roundabout Old Santa Fe New Mexico." 1940. Online at http://www.library.arizona.edu/ exhibits/pams/access.html

Luhan, Mabel Dodge. Edge of Taos Desert: An Escape to Reality. New York: Harcourt, Brace, and Company, 1937.

Lummis, Charles F. Mesa, Cañon and Pueblo: Our Wonderland of the Southwest, Its Marvels of Nature, Its Pageant of the Earth Building, Its Strange Peoples, Its Centuried Romance. New York: Century Co, 1925.

Lummis, Charles F. A Tramp across the Continent. Lincoln: U. of Nebraska P., 1892.

The Problem of Indian Administration (Meriam Report). Ed. Research, Institute for Government. Baltimore: Johns Hopkins Press, 1928.

Veblen, Thorstein. The Theory of the Leisure Class. 1899.

Wallace, Susan E. The Land of the Pueblos. New York: John B. Alden, 1888.

\section{Secondary sources}

Berke, Arnold, and Alexander Vertikoff. Mary Colter: Architect of the Southwest. New York: Princeton Architectural Press, 2002.

Berthier-Foglar, Susanne. Les Indiens pueblo du Nouveau-Mexique. Bordeaux: PU de Bordeaux, 2010.

Brandt, Elisabeth A. "On Secrecy and the Control of Knowledge: Taos Pueblo." In Stanton K.Tefft (ed.). Secrecy. A Cross-Cultural Perspective. New York: Human Science Press, 1980. 123-46. 
Bryant, Keith L. History of the Atchison, Topeka and Santa Fe Railway. Lincoln: U. of Nebraska P., 1974. Gallop, Alan. Buffalo Bill's British Wild West. Stroud, Gloucestershire: Sutton, 2001.

Howard, Kathleen L. and Diana F. Pardue. Inventing the Southwest. The Fred Harvey Company and Native American Art. Flagstaff, Arizona: Northland Publishing, 1996.

Jacobs, Margaret D. Engendered Encounters. Feminism and Pueblo Cultures, 1879-1934. Lincoln: U. of Nebraska P., 1999.

Kasson, Joy. Buffalo Bill's Wild West. Celebrity, Memory, and Popular History. New York: Hill and Wang, 2000.

Lange, Charles H. “The Role of Economics in Cochiti Pueblo Culture Change." American Anthropologist 55.5 (1953): 674-94. DOI: 10.1525/aa.1953.55.5.02a00070

McCannell, Dean. The Tourist: A New Theory of the Leisure Class. New York: Schocken Books, (1976) 1989.

McKercher, Bob, and Hillary du Cros. Cultural Tourism. The Partnership Between Tourism and Cultural Heritage Management. New York: The Haworth Hospitality Press, 2002.

Mullin, Molly H. Culture and the Marketplace. Gender, Art, and Value in the American Southwest. Durham: Duke UP, 2001.

Nash, Dennison. Anthropology of Tourism. Emerald Group Publishing Limited, 1996.

Prucha, Francis Paul. The Great Father: The United States Government and the American Indians. Vol. 1 and 2. Lincoln: U. of Nebraska P., 1984.

Smith, Melanie K. Issues in Cultural Tourism Studies. New York: Routledge, 2003.

Thomas, Nicholas. Colonialism's Culture. Anthropology, Travel and Government. Princeton NJ:

Princeton UP, 1994.

Urry, John. The Tourist Gaze. Theory, culture \& society. Second edition. ed. London ; Newbury Park [etc.]: Sage, [1990] 2002.

Urry, John, and Larsen Jonas. The Tourist Gaze 3.0. London: Sage, 2011.

Weigle, Martha. "From Desert to Disney World: the Santa Fe Railway and the Fred Harvey Compant Display the Southwest." Journal of Anthropological Research 45.1 (1989): 115-37.

Williams, Raymond Leslie, and Kevin G. Guerrieri. Culture and Customs of Colombia. Westport, CT: Greenwood Press, 1999.

Wilson, Chris The Myth of Santa Fe. Creating a Modern Regional Tradition. Albuquerque: University of New Mexico Press, 1997.

\section{NOTES}

1. The preferred nomenclature is "the Pueblo" (without the mark of the plural) for the people, and "the Pueblos" for the villages.

2. The term 'Indian' will be used here-in a historic and non-derogatory way-as 'Native American' is a post-1960s neologism and 'Amerindian' is reserved for anthropology or linguistics. Moreover, 'Indian Detours', as a brand, carried positive weight and the term 'Indian' was-and is -used in the administrative language in the United States. 


\section{ABSTRACTS}

In the late $19^{\text {th }}$ century and the first decades of the $20^{\text {th }}$ century the culture of leisure came to New Mexico and Indian Detours were organized for the "Anglo" tourists eager to witness the exotic (and so-called primitive) cultures within the United States. The authentic setting, the historic villages (i.e. Pueblos ${ }^{1}$ ), and the pre-industrial lifestyle of their inhabitants contributed to the tourists' experience of Otherness. The primitive way of life was not perceived by the tourists as being negative but as an escape from the pervasiveness of industry and urbanization. However, the wishes of the tourists clashed with the federal assimilation policies. Indian Commissioner Charles Burke issued numerous circulars to the Superintendents with strict rules concerning the exhibition of Indianness. He lamented the fact that Indians catering to the tourist industry postponed their assimilation as productive members of the American society. This paper also questions the intrusiveness and long-term impact of the "tourist gaze" upon Indians viewed at the train stations or in "Indian villages" set up in hotels or tourist destinations. New Mexican architecture and more particularly the Santa Fe Style have largely copied Pueblo vernacular. Under such extreme circumstances of colonial appropriation, coupled with the advent of the market economy, it is astounding that the Indians survived the onslaught of cultural tourism. Despite the marketing of tours targeting their villages and history as well as their arts and crafts production, the Pueblo have never given in to selling their ceremonies. They have set up barriers of secrecy limiting the primitivist experience of the tourists to what they wanted them to see. They have accepted the advice of traders in matters of styles of objects produced. But they have gradually taken over the management of the "tourist gaze" and have profited from the fetishization of all things Indian. With a lively market for tourist goods, it seems tourism has become a tool of integration while elements of what was formerly called "primitive" survive (non-Christian ceremonials for instance). Moreover, tourism has not destroyed those who were formerly the seemingly passive object of the "tourist gaze." (363)

Entre les dernières années du XIX ${ }^{\mathrm{e}}$ siècle et les premières décennies du $\mathrm{XX}^{\mathrm{e}}$ siècle, la culture du loisir a fait son apparition au Nouveau-Mexique et les voyages guidés sous le label Indian Detours ont été organisés pour les touristes Anglo-Américains (appelés Anglo dans le pays) en quête des cultures exotiques et dites « primitives » au sein même des États-Unis. Les lieux authentiques, les villages (pueblos) historiques et la vie préindustrielle de leurs habitants contribuaient à l'expérience de l'Altérité de la part des touristes. La vie "primitive » n'était pas perçue par les visiteurs comme un élément négatif mais comme un moyen d'échapper à l'industrialisation et à l'urbanisation devenues omniprésentes. Cependant, les souhaits des touristes entraient en conflit avec les politiques fédérales d'assimilation des Indiens. Le Commissaire aux Affaires Indiennes, Charles Burke, émit un grand nombre de circulaires aux Surintendants détaillant des règles strictes pour éviter que les Indiens ne deviennent des attractions foraines. Il déplorait en particulier le fait que les Indiens impliqués dans l'industrie touristique repoussaient leur assimilation en tant que membres productifs de la société américaine. Cet article pose aussi la question de l'intrusion et de l'impact à long terme du « regard touristique » sur les Indiens que l'on pouvait observer dans les gares ou les « villages Indiens » mis en place dans les hôtels et les lieux touristiques. L'architecture du Nouveau-Mexique, et plus particulièrement le style de Santa $\mathrm{Fe}$, ont largement puisé dans le vocabulaire architectural des Pueblos. Dans des circonstances aussi extrêmes d'appropriation coloniale, couplées à l'avènement de l'économie de marché, il est étonnant que les Indiens aient survécu à l'arrivée massive du tourisme culturel. Malgré le marketing des visites guidées ciblant leurs villages et leur histoire aussi bien que leur artisanat et leur art, les Pueblo n'ont jamais accepté de vendre leurs cérémonies. Ils ont mis en place une 
politique du secret qui forme une barrière protectrice autour de leurs rituels et qui limite l'expérience primitiviste des touristes à ce que les Indiens veulent bien leur montrer. Ils ont accepté le conseil des commerçants pour ce qui est des styles et du type d'objets produits. Toutefois, ils ont graduellement pris en main la gestion du « regard touristique » et ont profité de la fétichisation de tout ce qui est Indien. Dans le contexte d'une forte activité marketing en matière de produits pour le tourisme, il semblerait que ce dernier soit devenu un outil d'intégration, alors même que subsistent des traits culturels auparavant considérés "primitifs ", par exemple des cérémonies non-chrétiennes; au final, le tourisme n'a pas détruit ceux qui avaient été les objets apparemment passifs du « regard touristique ».

INDEX

Mots-clés: Indian Detours, Nouveau-Mexique, Santa Fe, Pueblo (Amérindiens)

Keywords: Indian Detours, New Mexico, Santa Fe, Pueblo (Native Americans)

\section{AUTHOR}

\section{SUSANNE BERTHIER-FOGLAR}

Université Grenoble Alpes, ILCEA4. Specialist of Native American history. Contact: susanne.berthier-foglar [at] univ-grenoble-alpes.fr 